\section{Cristianismo e Educação - Uma abordagem histórica da pedagogia da catequese}

\author{
Léo Antonio Perrucho Mittaraquis
}

\section{Resumo}

Ao longo da história do Ocidente, uma mentalidade, ou seja, um conjunto de manifestações (crenças, maneira de pensar, disposições psíquicas e morais), que caracterizam tanto uma coletividade, como um indivíduo foi consolidada em diversos aspectos, mas, principalmente nos que se referem à formação religiosa e intelectual, vale dizer, um conjunto de conhecimentos e habilidades específicos a determinados campos de atividade prática e espiritual, baseados na filiação a um sistema específico de pensamento ou crença que envolve uma posição filosófica, ética, metafísica. A esta, mentalidade deu-se o nome de cristianismo. No âmbito dessa doutrina, inúmeras linhas de pensamento foram desenvolvidas. Interessa, como objeto no presente estudo, o pensamento das ordens religiosas no tocante às praticas pedagógico-catequéticas.

Palavras-chave: Cristianismo. Catequese. Pedagogia.

\section{Chistianity and Education - a historical} approach to pedagogy catechesis 
O termo pedagogia vem do grego paidós (criança) e agogé (condução). O pedagogo, no sentido em que o termo foi absorvido pela língua latina e, posteriormente, pelas afiliadas, é aquele, portanto, que conduz crianças em seu processo formativo-educacional. Quanto ao termo catequese (de katêkhésis, palavra grega), este pode ser compreendido como a explicação dada, usualmente na forma oral, sobre conteúdo de cunho religioso, ou seja, a prática de instruir sobre a doutrina de uma religião.

Aproximando-se ambos os termos, estabelece-se, concomitantemente, a aproximação dos respectivos campos: educacional e religioso. Nos limites deste artigo, os termos são igualmente delimitados ao relacioná-los diretamente com a cultura cristã. Tal operação não é livre de dificuldade. Segundo Pierre Bourdieu:

[...] Não é coisa que se produza de uma assentada, por uma espécie de ato teórico inaugural, e o programa de observações ou de análises por meio do qual a operação se efetua não é um plano que se desenhe antecipadamente, à maneira de um engenheiro: é um trabalho de grande fôlego, que se realiza pouco a pouco, por retoques sucessivos, por toda uma série de correções, de emendas, sugeridos por o que se chama o ofício, quer dizer, esse conjunto de princípios práticos que orientam as opções ao mesmo tempo minúsculas e decisivas.

Não obstante Bourdieu tratar, na obra citada, das atribulações enfrentadas pelo pesquisador no campo das ciências sociais, estas se revelam similares no campo geral da pesquisa, ou seja, nos espaços estruturados onde se dão as atividades que têm por finalidade a descoberta de novos conhecimentos no domínio científico. Para que se possa produzir o devido constructo, desenvolvendo a averiguação sistemática no campo da História da Educação (com o objetivo de identificar relações de poder nas quais se reconhece ideias, valores e crenças, estas concernentes ao discurso pedagógico-catequético), percebe-se a necessidade de se efetuar a análise dos termos em questão: pedagogia e catequese.

É certo que já se abordou nas linhas supra estes termos aos quais se impõe, por força da problemática deste artigo, uma correlação. Entretanto é preciso aprofundar o diálogo com o objeto, vale dizer, buscar o entendimento das condições histórico-sociais do tempo e do espaço que favoreceram a manifestação de seus discursos, e não necessariamente de suas origens. $\mathrm{O}$ que redunda em buscar referenciais teóricos e históricos especificamente direcionados ao tema. Estes trazem os acontecimentos de uma longínqua época, de eventos memoráveis que evidenciaram as particularidades de um novo período. Inclui-se, indiscutivelmente, a interpretação. $\mathrm{O}$ discurso contido na bibliografia é a materialização de diversos olhares, os quais, mesmo em um mesmo campo, divergem quanto à perspectiva. Diversos são os pesos e as medidas. Na tentativa de lidar com essa flutuabilidade de valores busca-se um lócus teórico-metodológico. No campo histórico em que a presente produção se inscreve, as referências se ampliam em número e em possibilidades: a História Nova e a História Cultural.

O documento, compreendido, tecnicamente como "unidade de registro de informações, qualquer que seja o suporte" quer que se busque em Foucault, mais especificamente em A Arqueologia do Saber, a noção de documento/monumento. $\mathrm{O}$ historiador francês insiste, também, sobre a necessidade de: "Delimitar, explicar as lacunas, os silêncios da história, e assentá-la tanto sobre esses vazios, quanto sobre os cheios que sobreviveram". Le Goff defende igualmente que uma nova metodologia de apreensão cronológica dos acontecimentos seja aplicada, levando mais em consideração sua possibilidade de produção de efeitos na história do que a indicação do dia ou da época da sua ocorrência. Por fim, insiste em que se evite produzir paralelos de forma excessivamente arbitrária, identificando elementos aparentemente similares entre classificações de sistemas econômicos, políticos e sociais espacial e temporalmente distantes.

As três recomendações do autor de O Deus da ldade Média devem certamente ser levadas em consideração. $\mathrm{E}_{\iota}$ crer-se neste trabalho, que a bibliografia consultada, a qual não só analisa, relata, mas, também, reproduz documentos é, tanto quanto antigos pergaminhos, um corpo de documentos que, mediante o discurso dos autores, reproduzem (e reorientam) o discurso dos antigos documentos dos quais os estudiosos se valem no estabelecer de suas teses. Assim, em um primeiro momento, as 
informações apreendidas das obras consultadas devem: sofrer o questionamento quanto à intencionalidade dos discursos reproduzidos; serem analisadas quanto à densidade histórica, evitando valorar pela simples datação que obedece a sequência arbitrária de começo meio e fim; somente aproximadas quando de fato estabelecerem um diálogo que se sustente por convergências apoiadas em referências afins de época e lugar, e os aspectos histórico-sociais a estes inerentes. Para o presente artigo, tal prática proposta (o descarte de certas ações humanas) teria um efeito engessador. Os detalhes apontados por Burke na citação podem ser percebidos em Werner Jaeger. Sua obra, Cristianismo e Paidéia griega, onde o autor relata ao mesmo tempo em que analisa a gênese da doutrina cristã, a profunda influência que esta recebeu da cultura grega.

Desde el momento em que desperto la conciencia histórica moderna, em lá segunda mitad del siglo XVIII, los eruditos em teologia cayeron em la cuenta - al analizar y discribir el gran proceso histórico que se inició com o nacimiento de la nueva religion - de que los fatores que determinaron la forma final de la tradicion cristiana, la civilización griega ejerció uma influencia profunda em la mente cristiana.

Jaeger prossegue em seus estudos sobre a íntima relação que se deu entre a Paideia grega e a doutrina cristã recém-surgida, tomando como referência a produção filosófica de São Clemente Romano:

El documento literário más antiguo de la religion cristiana. Al que es possible fijar uma fecha poço posterior al tiempo de los apostoles es la Carta de San Clemente Romano a los coríntios, escrita em la última década del siglo I. Es interessante notar el cambio sofrido por la mentalidade cristiana em los trinta años transcurridos desde la muerte de San Pablo, que había escrito a esta misma Iglesia de Corinto a fim de poner fin a las disputas entre sus grupos y a las diferencias em su interpretacion de la fé cristiana.

A produção desse documento por São Clemente Romano, tem como intenção demonstrar o quão desastroso seria a permanência dos conflitos entre as facções religiosas. Contudo, não é este o ponto de interesse imedia- to para o desenvolvimento dos argumentos que inclusos na estruturação deste artigo. No processo de definição e abordagem do objeto em estudo, é significativo compreender que São Clemente Romano se vale, para compor seus argumentos, da antiga arte retórica. Segundo Jaeger, o religioso se utiliza das normas que regem a eloquência política. O tom apaziguador do discurso epistolar de São Clemente Romano busca referências na retórica dos educadores políticos que atuaram largamente durante a época clássica da polis grega.

\section{A genealogia da pedagogia da catequese}

Antes de tudo, cabe observar, aqui, que o termo genealogia é utilizado a partir da perspectiva nietzscheana-foucaultiana. Este artigo realiza uma abordagem genealógica, sem precisar inícios históricos, senão sugerindo interações entre ocorrências de maior ou menor magnitude. Evita-se a visão positivista - pretensa identificadora de origens. Não se percebe um encadeamento linear consequente, mas, sim, a dinâmica de campos diversos. Opta-se, aqui, portanto, iniciar o exercício de elaboração da genealogia da pedagogia da catequese pelo encontro ocorrido entre o denominado cristianismo primitivo e a Paideia grega. O objeto de interesse aqui trabalhado requer, antes de se debruçar diretamente sobre ele, que se elabore uma linha histórica (não necessariamente contínua) que se percebe nas primeiras manifestações cristãs, na antiguidade. E a obra de Jaeger é fundamental para o entendimento desse processo. E, por isso, dá-se continuidade nas considerações sobre a mesma aqui: o discurso clementino é um discurso voltado tanto para a ordem política como, e principalmente, para a salvação, ou seja, para a ascensão (ascese; áskesis: exercício prático) moral da alma. É o discurso de um saber. Este é um saber para a verdade. Sobre este aspecto, diz Foucault: "Não é por referência a uma instância como a lei que a áskesis se estabelece e desenvolve suas técnicas. A áskesis é na realidade uma prática da verdade. $A$ áskesis não é uma maneira de submeter o sujeito à lei: é uma maneira de ligar o sujeito à verdade".

Contudo, não significa que o sujeito deva desconhecer às leis do mundo, senão identificá-las com as leis eternas, 
ou seja, as primeiras devem se submeter às últimas. Segundo Jaeger, São Clemente Romano compreende a ordenação do mundo a partir das práticas éticas e políticas determinadas pelas leis divinas, estas que são mais bem compreendidas a partir de uma filosofia cosmológica. Segundo Jaeger:

La paideia griega habia hecho lo mismo, pues siempre hacia derivar sus reglas sobre la conducta humana y social de las leyes divinas del universo, a las que daba el nombre de"naturaleza" (physis). Los interpretes cristianos debieram recordar que este concepto griego de la naturaleza no es idêntico ao naturalismo em sentido moderno, sino más bien casi opuesto. Este aspecto cósmico del problema de la paz em el mundo humano parece ante los ojos del lectos no solo en el famoso capitulo 20 de la carta; em los capítulos siguientes se mantiene la misma perspectiva, aunque a veces se la combina com la aplicacion prática de este punto de vista al caso em quastion. Esto no hace que, a los ojos de um griego, las reflexiones acerca de los princípios sean menos filosóficas, pues la teoria y a la vida deben marchar siempre juntas, y solo cuando se las comprende em esta forma puede el filósofo sostener que él imparte la paidéia verdadera.

O exemplo de relações mantidas entre a doutrina cristã e a Paideia grega buscado em Jaeger, notadamente na obra Cristianismo primitivo y paidéia griega, legitima, crer-se, esta complexa operação de levantamento das origens do discurso pedagógico cristão.

A Paideia cristã pode, em termos gerais, ser entendida como uma apropriação e recaracterização (o que, perspectivamente, pressupõe um redirecionamento) da Paidéia grega, juntamente com a cultura romana, isto é, uma reconfiguração do pensamento clássico adaptado às exigências de fundamentação e consolidação do que poderíamos denominar uma nova concepção de mundo e, por conseguinte, uma revolucionária compreensão sobre como as práticas educativas deveriam ser elaboradas e aplicadas.

Ao pretender-se, aqui, comentar uma expressão constituída por dois termos, sendo o primeiro de origem grega (o que significa dizer: produto da cultura grega), crer-se ser recomendável a apresentação deste: paidéia significa, segundo a professora de história da filosofia e de filosofia política, Marilena Chauí:

\begin{abstract}
Educação ou cultivo das crianças, instrução, cultura. O verbo paideûo significa: educar uma criança (paîs-paidós, em grego), instruir, formar, dar formação, ensinar os valores, os ofícios, as técnicas, transmitir idéias e valores para formar o espírito e o caráter, formar para um gênero de vida, da mesma família é a palavra Paideia, ação de educar, educação, cultura.
\end{abstract}

Uma palavra, vários significados, os quais, ainda que com sentidos semelhantes (não necessariamente iguais), remetem ao desconforto provocado pela multiplicidade possível de interpretações. Cabe aqui, diante disso, ater-se às delimitações. Talvez por isso Werner Jaeger alerte que Paideia é um termo de difícil definição, pois "Não se pode evitar o emprego de expressões modernas como civilização, cultura, tradição, literatura e educação; nenhuma delas, porém, coincide realmente com o que os gregos entendiam por Paideia".

Este é um problema que, em vista da natureza do presente estudo, deve-se mencionar. Contudo, não será aqui que se deitará sobre o termo um olhar filológico. No que concerne ao objeto sob análise, o termo grego Paideia, no espectro de definição proposto por Chauí, atende plenamente às necessidades deste artigo. Mais ainda quando adjetivado pelo termo de (origem latina), cristã. Assim, tem-se a Paideia cristã como um campo para a formação do educador e do educando (agentes sociais), visando o viver na cidade dos homens e o fazer por merecer a cidade de Deus. No tratamento do objeto proposto, recorreu-se, além de outras, também a duas obras consideradas, diante dos objetivos deste artigo, essenciais: História da Educação na Idade Média, de Ruy Afonso da Costa Nunes (1979), e História da Pedagogia, de Franco Cambi (1999).

O livro de Nunes, tomando-o, primeiramente, na totalidade, é, antes de tudo, uma cruzada contra a visão preconceituosa, comumente nutrida, em relação ao medievo, na tentativa, segundo o autor, "de deixar o leitor 
atento a outros dislates que ocorram mundo afora sobre assuntos do período medieval". No capítulo em questão, Nunes vale-se do exemplo negativo de Roger Clausse, autor de Critique materialiste de l'educacion, citado por Arnoud Clausse (o sobrenome é o mesmo), que afirma, com evidente intenção redutora, ser a Idade Média um período dominado por "concepções ascéticas".

Nunes rebate esse argumento observando que "também se pode afirmar da Renascença e dos séculos XVII, XVIII, XIX e XX que tiveram e têm concepções ascéticas". $\mathrm{O}$ ascetismo, em maior ou menor grau, não é, necessariamente, uma característica predominante apenas no pensamento medieval. É próprio da conduta do místico (no caso, do cristão) em qualquer época, ainda que se devam observar as contingências. A posição bem definida e esclarecedora de Nunes tem como objetivo combater, com as armas do conhecimento, a visão obscurantista com a qual é percebido o período medieval, justamente por não concordar em absoluto com tal entendimento: a Idade Média como tempo de trevas e de retrocesso, um entendimento deveras equivocado. Logra trazer à luz aspectos significativos das práticas educativas de então.

$\mathrm{Na}$ verdade, as concepções pedagógicas que tomarão corpo ao longo do medievo ocidental cristão, mais especificamente, do século $V$ ao século XII, devem ser percebidas já na antiguidade cristã, ou seja, nos últimos momentos do Império Romano, quando pensadores de então se voltam para uma nascente visão de mundo em que se encontra latente o germe do que num futuro próximo seria conhecido como Cristianismo. Esse fato (ainda que se possa levar em conta uma relativização possível, de acordo com a perspectiva histórica aplicada) é bem ilustrado por Nunes, o qual afirma que

Desde o fim do mundo antigo e o início da Idade Média, por conseguinte, os monges concorreram para a transmissão do legado cultural antigo aos povos germânicos das cristandades medievais. De um lado, foram os principais propagandistas da religião cristã na Europa, tendo evangelizado os anglo-saxões, os teutões, os escandinavos, os eslavos e os húngaros. Por outro lado, transmitiram-Ihes, também, as obras literárias e as concepções filosóficas e educa- cionais dos romanos, especialmente através do benfazejo labor dos copistas que asseguraram a preservação dos livros antigos.

O processo de fortalecimento desse pensamento voltado, ao mesmo tempo, para a educação visando o cotidiano (as artes liberais) e a ascensão espiritual, pois, além do ideal clássico, "impunha-se sobranceiro o propósito de se plasmar o perfeito cristão", encontra campo vasto no vácuo deixado pela decadência da cultura romana, isto é, no enfraquecimento dos parâmetros impostos por essa cultura no que diz respeito inclusive aos aspectos políticos e econômico-administrativos, o que solapa, conseqüentemente, a idéia do homem público, do homem nobre e forte. A força será outra, autorizada pela Divindade através da fé e da graça. A força, inclusive, para se perceber fraco e humilde, reconhecendo as limitações da carne e investindo na potência espiritual, no poder de redenção através da salvação da alma.

Outro tipo de Homem será pensado e formado daí por diante. A educação, sob o entendimento cristão do que seja a vida abordará, como dissemos, duas realidades, a mundana e a espiritual. Claro que, pela natureza mesma do movimento histórico-cultural de gradativa prevalência do pensamento cristão, a segunda realidade deverá receber especial atenção, pois se trata nada mais, nada menos, da salvação (ou, se no incorrer impiedoso de graves erros, da danação) eterna. Quanto a esta finalidade, característica de uma revolução de cunho religioso, visando a re-formação do sujeito humano, Nunes diz que, buscando o ideal estado de graça,

Esse era, e ainda é, o supremo objetivo educacional do povo cristão. Do ponto de vista pedagógico, como vimos em nosso livro História da Educação na Antiguidade Cristã, Santo Agostinho legou aos educadores medievais os princípios aos educadores medievais os princípios pelos quais eles se pautaram quanto à organização dos estudos: os jovens devem dedicar-se ao aprendizado das artes liberais e mecânicas e à filosofia, a fim de aproveitarem ainda mais no estudo da Sagrada Escritura que ensina o que é preciso saber e praticar para alcançar a vida eterna e feliz. 
A passagem do Mundo Antigo para o que seria, na Renascença, denominado Idade Média, como uma conflituosa época de transição, assistiu ao desaparecimento das instituições, inclusive as voltadas para a educação, como no caso de Roma, onde o ensino público "se desmantelou após as invasões dos bárbaros, embora o declínio fosse gradual e o cultivo das letras não desaparecesse completamente, pois, apesar das invasões germânicas, as escolas continuaram a existir". Todavia a época é decididamente outra: a Igreja busca uma presença consolidada e, diante do desaparecimento das instituições oficiais, surgem, "entre o fim do século IV e o começo do século V, as escolas paroquiais, sob a administração exclusivamente eclesiástica. Aliás, antes mesmo da desagregação do Império Romano, o ensino oficial entrara em declínio".

O surgimento das escolas medievais cristãs foi, também, uma resposta à necessidade de se atender a necessidade de formação dos desejosos em entrar para a vida religiosa. Uma estrutura foi, aos poucos, cuidadosamente elaborada, com o intuito de estabelecer as normas para a educação de jovens, compreendendo serem estes partícipes de um meio onde a fé estabelecia as referências para o exercício de um ethos diametralmente diverso do exercido na antiguidade clássica:

O nível elementar desse ensino era representado pelas escolas paroquiais e o superior, pelas episcopais. A escola paroquial funcionava na igreja matriz da paróquia ou na casa paroquial, e a escola episcopal alojava-se na igreja catedral ou na residência do bispo. Aliás, desde os primórdios da lgreja, no período patrístico, os bispos tratavam de formar ao seu lado os colaboradores do seu ministério pastoral, assim como os concílios e os sínodos orientais e ocidentais foram legislando a respeito dos requisitos para a ordenação sacerdotal e para a imposição dos ministérios.

Mas, se o ethos diante do mundo e do espírito deveria ser - sob a ótica cristã - outro que não o da antiguidade clássica, vale dizer, que não o defendido pela cultura greco-romana, nem por isso a produção artístico-filosófica foi totalmente relegada ao esquecimento. É certo que, como afirma Nunes, não obstante ser recomendado aos jovens o estudo da filosofia, na educação monástica o pensamento filosófico não adquiriu peso. O que não seria verdade afirmar, também segundo Nunes, sobre as escolas episcopais, principalmente na Inglaterra, se nos basta como exemplo a Cantuária, onde Teodoro de Tarso, erudito formado nas letras profanas e nas sagradas, chegou em 668, propagando o conhecimento da literatura e da língua grega, pois foi naquele lugar que a cultura helenística encontrou terreno fértil.

Assim, o que se vê é, como se afirmou antes, não uma negação absoluta da cultura clássica, senão uma transformação e adaptação de suas propostas na construção de sistemas visando a compreensão do mundo, ainda que, nesse processo, impere a aceitação do Mistério, buscando-se entender e aceitar a Palavra. Nesse sentido, a Paideia grega torna-se referência para a Paideia cristã. Esta, contudo, estabelece outra leitura do mundo, onde o campo educacional é um espaço essencial para a representação de uma prática educativa jamais pensada. Ainda que Nunes não trate, explicitamente, da ideia de uma Paideia cristã, seus estudos, riquíssimos em informações e análises, oferecem os lastros exigidos pelo caráter teórico com o qual se acerca, neste artigo, do objeto.

Essa torção radical das perspectivas do homem diante da natureza, de si mesmo, do outro e do insondável, resultará num novo ethos pedagógico. Para compreender-se melhor esse processo, recorre-se, então, a Franco Cambi:

\begin{abstract}
Com a difusão do cristianismo, depois, com sua legitimação político - religiosa sob Constantino, virá certamente criar-se uma significativa ruptura também no terreno educativo: os cristãos depreciam a retórica e a cultura dos pagãos em geral, atacam as escolas que transmitem uma literatura contrária ao espírito cristão e orientada para valores diferentes dos evangélicos.
\end{abstract}

Pode-se, então, afirmar, em um primeiro momento, o repúdio incondicional manifestado pelo cristão em relação à cultura pagã. Evite-se, entretanto, de cometer-se um erro crasso: esquecer que a cultura cristã, para rebater a pagã, teve de conhecer a produção desta última. As formas adotadas para realizar a crítica negativa às obras foram definidas a partir da leitura dos pagãos. 
Segundo Cambi, vê-se, agora, diante de um mundo concebido, no sentido de apreensão, de uma forma totalmente nova. $\mathrm{O}$ homem, como pensado na antiguidade clássica, converte-se. Crê, então, em um só Deus, sabe-se limitado e dependente, e não deve exercer a força arbitrariamente, pois, acima de suas decisões, de seus atos, existe o Juiz, e a este nada escapa. Eis a nova realidade. $O$ tempo revela-se como finito, haverá um fim do mundo e um julgamento. É preciso, portanto, preparar-se.

Esse homem é um sujeito voltado para a igualdade e para a solidariedade. Vê grande valor na pobreza e na castidade. O trabalho braçal também é visto de uma maneira diversa de como foi valorado no mundo antigo. Ganhar o pão com o suor do rosto é condição essencial para se pertencer à comunidade cristã. Segundo Cambi, eis um tempo em que se abole "qualquer desprezo pelos trabalhos 'baixos', manuais, e se coloca num plano de colaboração recíproca os patrões e os escravos, os serviçais, os empregadores e os dependentes".

O mundo cristão é constituído por tempos e espaços mantidos pelos ditames contidos no Evangelho. A Igreja, sua representação maior, se fortalece administradas pelos dedicados agentes sociais, os padres. Representação revolucionária, pois é, não obstante manter algumas referências, uma proposta de ruptura. Uma cultura que firma outro papel para o crente na sociedade. Uma sociedade em que valem os "vínculos espirituais entre os iguais e não as relações hierárquicas, assimétricas, de domínio e de imposição ou as identidades étnicas e locais, superadas aqui na universalidade da mensagem".

No cenário revolucionário cristão, as práticas educativas exercem um papel essencial: elas são mesmo o suporte teórico e empírico da nova mentalidade. Os padres da Igreja têm reconhecido o seu poder de formar. Fazem-se necessários no processo de evangelização que deve disseminar-se pelo mundo. A perspectiva pedagógica, até então legitimada pelas escolas pagãs, visa, agora, um conhecimento que tem por finalidade a salvação espiritual a partir e em direção a um único ponto: um só Deus. Ciente disso, a fé deve irmanar-se ao intelecto em busca do conhecimento. E se é possível contar com outros dois pontos de apoio (família e Igreja), pode-se notar a seguinte expectativa:

\begin{abstract}
Toda sociedade enquanto religiosamente orientada tornar-se educadora; mas mudam também os ideais formativos (à paidéia clássica contrapõe-se a paidéia christiana, centrada na figura do (risto) e os próprios processos de teorização pedagógica, que se orientam e se regulam segundo o princípio religioso e teológico (e não segundo o antropológico e teorético). A revolução do cristianismo é também uma revolução pedagógica e educativa, que durante muito tempo irá marcar o Ocidente, constituindo uma das suas complexas, mas fundamentais matrizes.
\end{abstract}

As representações revolucionárias no campo educacional da Alta Idade Média estão presentes, já como práticas de formação, isto é, práticas educativas encontradas nos mais antigos documentos cristãos. Naquele momento, não é ainda precisamente uma proposta pedagógica que se delineia, senão um ethos que é proposto a partir de uma compreensão diversa da presente na antiguidade clássica. Há uma substituição de termos, vale dizer, a linguagem (manifestada como sermão, diferenciando-se do conceito clássico de discurso) recorre a palavras que trazem uma qualificação distinta, representando um novo papel na comunidade cristã, pois o cristão deve ser formado e educado num sentido oposto ao do mundo antigo. O que antes era visto como sintomas negativos, como ser frágil e tolerante, é então valorizado e deslocado para o centro das ações humanas que se pretendem sintonizadas com os preceitos do cristianismo.

As praticas educativas, para que sejam percebidas como atos manifestos das representações revolucionárias, linhas de ação da Paideia cristã, sustentam-se sobre quatro pilares, isto é, segundo Cambi, sobre quatro textos:

Os Evangelhos, como sendo aspectos fundamentais da educação cristã: é projetada e guiada por um mestre-profeta (como Cristo), que fala contra os hábitos correntes e quer provocar uma catástrofe interior, uma renovação espiritual, através de uma mensagem que inquieta e desafia a tradição e a indiferença subjetiva; as Epístolas de São Paulo, uma visão da mensagem 
cristã: mais dramática, mais inquieta, mais disciplinar, passada pelo filtro da cultura hebraica e da helenístico-romana; o Apocalipse: tensão escatológica na história e da regeneração final do homem, temas que iluminam um caminho educativo próprio das comunidades cristãs; os Atos dos Apóstolos, traz em seu centro a ação educativa das primeiras, e até mesmo primeiríssimas, comunidades cristãs.

Sobre estes pilares, os padres, como autores de uma proposta formativo-educativa, encontram suportes para elaborar e aplicar outro segmento da Paideia cristã: o eixo pedagógico. Segundo Cambi:

No período que vai da morte de Cristo à época constantiniana, a Igreja vai organizando suas próprias práticas educativas e sua própria teorização pedagógica, sob o influxo, sobretudo, da cultura helenística, mas também da evolução das comunidades cristãs.

$\mathrm{Na}$ evolução das comunidades cristãs revela-se, então, a partir dos ensinamentos de Cristo, uma atenção especial com relação às crianças. $O$ eixo pedagógico se define, ainda que isso não signifique que a Igreja centrará toda sua atenção na educação infanto-juvenil. $\mathrm{O}$ que se procura destacar aqui é que uma espécie de puericultura incipiente se anuncia. Pois se a família passa a ser vista como célula-mãe de uma sociedade voltada para o culto a Deus, é de se esperar que as crianças sejam percebidas de maneira um tanto especial. Sobre isso, comenta Cambi:

Entrementes, fixam-se também algumas práticas educativas ligadas à práxis comunitária, relativas à família (que se modela pelo amor recíproco e dedicação aos filhos, embora os "governe" com autoridade), relativas à Igreja que vê encarnar-se nas crianças o estado de graça (segundo os apelos de Cristo que convidava a tornar-se criança e deixar vir a ele os pequeninos, segundo a idéia de que o batismo renova a alma, fazendo-a voltar à "pureza" infantil) e relativas ao papel que as crianças ocupam na própria comunidade (onde são, ao mesmo tempo, valorizadas e marginalizadas).

Contudo, as práticas revolucionárias no campo educacional deveriam visar uma amplitude bem maior, através do que Cambi chama de ação educativa, deslocando o poder civil do centro das decisões, substituindo-o como instituição reguladora formativa e administrativa. A Paideia cristã pressupõe, em suas práticas revolucionárias, uma mentalidade de governo (caracterizado por duas linhas: uma religiosa e outra civil), isto é, na ação educativa inclui-se a disposição de agir como instituição maior, fundamentada em um corpo doutrinário que a autoriza a impor normas de conduta à comunidade, exercitando "um pensamento jurídico e teológico modelado pela tradição helenístico-romana". Isso nos leva a concluir que não há um rompimento total dos laços com a cultura filosófica greco-romana, os educadores retomam esse conhecimento, reorganizam-no sob a luz das Sagradas Escrituras. Portanto, ainda que pese uma ação de ruptura, as marcas do mundo clássico permanecem. E ao tratar do que fica do pensamento clássico, Cambi recorda que Logos e Verbum têm, na origem, o mesmo sentido:

A começar já dos Evangelhos (do IV), a marca da cultura grega se fixa dentro do discurso cristão ("In principio erat Verbum et Verbum erat apud Deum et Deum erat Verbum": é o começo do Evangelho de São João, onde Verbum transcreve a noção helênica de Logos), mas é, sobretudo, no tempo dos Apologistas (que defendem o cristianismo das acusações mais variadas: idolatria, subversão, etc.) e, depois, dos Padres (os intérpretes teóricos e orgânicos da mensagem cristã) que se inicia a simbiose entre cristianismo e helenismo.

Cambi cita como um dos principais agentes promotores de aproximações entre a visão de mundo helenística (mais especificamente o platonismo) com o pensamento cristão: São Justino. Este experimentou diretamente aspectos dessa proposta aproximativa. Como filósofo, aproximou Platão de Cristo, defendendo o pensamento cristão como a forma mais elaborada de ascese em direção a Deus, o que significa uma aceitação, dentro do processo de inovação, de valores próprios da antiga cultura helênica, pois, segundo o santo, além da fé (o simples e direto ato de crer) é possível e recomendável que razão esteja a serviço do conhecimento das coisas divinas. É sabido, porém, que nem todos concordavam com a opinião de São Justino. Segundo Cambi, um aluno do santo, Taciano da Síria, 
Exprime uma forte oposição à cultura grega, em todas as suas formas (desde a retórica - que serve à injustiça e à calúnia - até a arte - que descreve "batalhas, os amores dos deuses, a corrupção da alma" - e a filosofia - que é saber litigioso e arrogante, ávido e fantasioso), referindo-se à tradição gnóstica (animística e demonística na concepção do cosmos, racionalista na de Deus).

Posições antagônicas, como a de Taciano, não são as que prevalecem. A Paideia grega, como dissemos, permanecerá presente na Paideia cristã, ainda que não devamos afirmar uma solução de continuidade. Mas o fato é que a Paideia cristã é outra maneira de se buscar a formação e a educação do homem, não tão diversa, em vários aspectos, da predecessora. O que não deve causar surpresa se é sabido, ao menos, que ambas as propostas de Paideia, a da antiguidade clássica e a que surge no inicio da Idade Média têm muito em comum: são partes do que se entende como sendo a cultura ocidental. O ocidente é certamente cristão. Nesse contexto, as práticas revolucionárias educativas se revigoram, avançam em direção à constituição de um Estado devidamente organizado. É essa a defesa de Clemente de Alexandria, em sua Epístola aos Coríntios, juntamente com Origines. Esses dois sábios

Deram vida à Paideia cristã, reinterpretando em sentido cristão a Bíblia e relendo a filosofia grega à luz de Platão, mas também unindo filologia e interpretação. Clemente, com seu Paedagogus, coloca como modelo a Paideia helênica, mas também afirma que esta só se realiza plenamente no cristianismo.

Por causa dessa relação quase que simbiótica (a Paideia grega revive através da Paideia cristã, a qual, por sua vez, se mantém a medida que cultiva aspectos da educação clássica), algo como uma apropriação de uma proposta de método significando, ao mesmo tempo, o reconhecimento de sua importância, é que foi possível inserir, tomando como referência a tradição filosófica, a idéia de formação e educação conforme compreendida no mundo antigo. A Paideia grega foi, sem dúvida, valorizada pelos intelectuais cristãos .

Mas, diante da doutrina cristã, revelou-se incompleta, fragmentada, realizando-se somente em contato com o cristianismo tido como a verdade total. Nesse contato, é que a filosofia cristã se configura, como também sua proposta pedagógica, ambas buscando a legitimação da fé, sob a direção da Igreja, fundamentando uma consistente aliança entre crença e conhecimento, ainda que a primeira não se submeta completamente à racionalização, pois existirão sempre as verdades inerentes ao Mistério, inacessíveis pela via da razão. Não se deve esquecer de que a Paideia cristã é uma metodologia de ensino (seja para a vida cotidiana, seja para as inquietações do intelecto) voltada para a salvação. É certo que, ao lado da fé, também existem no homem a ciência e a arte. Estas, contudo, sob uma perspectiva pedagógica cristã, não são fins, mas apenas meios auxiliares, inúteis se não guiados pela luz esclarecedora da Palavra. Ao mesmo tempo, é preciso ter em mente que a construção de uma Paideia cristã foi um ato de resposta a um momento de transição: um mundo (o antigo) se finava, sendo esse fim representado pela queda do Império Romano do Ocidente; outro mundo surgia, e neste, um novo homem e uma nova forma de conceber o poder divino se anunciava. Nesse contexto, por conseguinte, a educação precisa responder às necessidades concernentes à uma reelaboração do ethos: uma nova visão religiosa pressupondo nova ideia de formação. Quanto a isso, nos diz Cambi:

\begin{abstract}
O diálogo entre pensamento grego e cristianismo fundou a primeira tradição filosófica da nova religião e tocou, em particular, o âmbito da teorização pedagógica que incorporou e transcreveu a noção de paidéia, embora a experiência cristã deixasse conviver ao lado uma visão educativa rigorista e anti-intelectual, de inspiração rigidamente religiosa. A ruptura cristã também em pedagogia foi sensível, mas as categorias que vinham organizando aquela experiência mantiveram uma profunda continuidade com a reflexão clássica que operou durante toda a Idade Média e depois na própria Idade Moderna.
\end{abstract}

Afirma-se, aqui, pois, uma análise da formação de um projeto pedagógico revolucionário que visou redimensionar o espírito, desenvolvendo valores relacionados à interioridade, ao mesmo tempo em que formou mentalidades no entendimento da realidade exterior e mundana, concebendo esta como necessá- 
ria, mas temporária, pois, a Paideia cristã se propôs, sistematicamente, a remeter o sujeito em direção ao Mistério que legitima a poderosa, constante e salvadora presença do Divino.

A pedagogia da catequese se manifesta no cenário formado pelas ocorrências que constituíram todo o processo que resultou no fim da Antiguidade. Nasce no seio de um movimento revolucionário, o Cristianismo. Entre o fim do mundo antigo e o início do medievo, deu-se um rearranjo estrutural no campo histórico-educacional (no quadro histórico-social), processo este que forneceu as condições propícias a um novo ideal, isto é, a um objeto de mais alta aspiração, de forma a orientar as práticas educativas.

O Cristianismo primitivo se vê diante da necessidade de se afastar da visão pedagógica greco-romana. Assim, um sentimento contrário se manifestou entre a visão de mundo helênica e a cristã. Situação de conflito que, até então, mantinha-se, pode-se dizer, latente. Mas a ruína da cultura antiga permitiu que se divisassem os valores constitutivos do campo educacional, onde se dava, em maior ou menor grau, conforme o momento, o embate entre os agentes representantes de ambas as linhas de pensamento. Os aspectos morais e religiosos passaram a sobrepor as referências intelectuais e estéticas. A fragmentação cultural do mundo antigo (grego e romano) foi, paradoxalmente, o motor dessa revolução pedagógica, voltada para a salvação da alma.

\section{O temor do Senhor como referência na pedago- gia da catequese}

$\mathrm{Na}$ continuidade desse levantamento genealógico da educação catequética é que se vislumbrou o temor do senhor como um princípio pedagógico nas práticas educativas dos padres apostólicos na antiguidade cristã. Este se ambienta no processo histórico-cultural de ruptura (ao fim do mundo antigo) entre o pensamento cristão (cristianismo primitivo) e a visão de mundo estético-intelectual pagã. É uma quebra de continuidade diretamente relacionada à queda do Império Romano do Ocidente. Eis uma nova norma de proceder, isto é, de conduta.
Stan-Michel Pellistrandi, ao observar que os adeptos na nova crença tinham por regra evitar objetos e palavras que evocassem a mitologia, as futilidades dos idólatras, cita Clemente de Alexandria:

\begin{abstract}
Nossos sinetes devem ser ornamentados com uma pomba ou um peixe, ou um navio com as velas abertas, ou uma lira como o fez Policrato, ou a âncora que Seleuco fez gravar na sua pedra. Se um pescador está representado, lembrar-nos-á o apóstolo e as crianças resgatadas pela água. Mais guardai-vos de reproduzir ídolos: porque mesmo olhá-los é proibido. Não queremos, também, nem gládio, nem arco, nós que procuramos a paz; nem taça, nós que devemos observar a temperança.
\end{abstract}

Observe-se, contudo, de que o presente recorte temporal, entre os séculos II e V, de interesse para nosso estudo, comporta, também, eventos que constituem parte do processo de desintegração do modus vivendi romano em seus aspectos político, econômico e religioso. Para a maioria dos historiadores (incluindo os que se dedicam à história da educação), a ruína total dessa unidade política que abarcou e dominou tantos territórios (e seus povos) se deu ao final da primeira metade do século V. É o que lemos em Ruy Afonso da Costa Nunes:

\begin{abstract}
A idade média foi a expressão imprópria aplicada ao período de mil anos que se iniciou no Ocidente com a derrocada do Império Romano em 476, quando se deu a queda de Roma sob o reinado de Rômulo Augústulo, enquanto em Bizâncio se mantinha o Império Romano do Oriente que se prolongaria até a queda de Constantinopla sob os ataques dos turcos em 1453.
\end{abstract}

Tendo demonstrado o cuidado com as referências cronológicas, volta-se o estudo para o tema. A primeira hipótese é que um tipo de sentimento foi produzido e estimulado a partir de determinadas ações pedagógicas as quais representam a intenção de iniciar as crianças no processo de familiaridade com a Palavra. A segunda hipótese, portanto, é a seguinte: no desempenho da função do ensino apostólico-pedagógico, historicamente situado na antiguidade cristã, o estado afetivo a que o catecúmeno era levado, caracterizou-se pela digna submissão 
e serenidade diante do poder divino. O que permite elaborar a terceira hipótese: durante período que Luzuriaga denomina de primeira época (entre os séculos II e V), as práticas educativas se deram na emergente comunidade cristã primitiva, entre uma Igreja ainda incipiente e a família. Esse espaço de tempo configura-se como nosso recorte, não só pela delimitação conveniente, mas, também, pelo fato de ser justamente a fase em que as práticas educativas (sobre as quais se debruça no presente estudo) ocorreram.

Entre o fim do mundo antigo e o início do medievo, deu-se um rearranjo estrutural no campo histórico-educacional (no quadro histórico-social), processo este que forneceu as condições propícias a um novo ideal, isto é, a um objeto de mais alta aspiração, de forma a orientar as práticas educativas. Os primeiros pedagogos cristãos perceberam que "a literatura e as escolas da civilização antiga forneciam os baluartes mais sólidos para o paganismo". As práticas religiosas entre gregos e romanos tomavam os conceitos políticos como valores principais. A prática pedagógica cristã primitiva, por seu lado, através dos padres apostólicos, radicalizou distinções que resultaram na separação da religião e política. Diz-nos Monroe:

\begin{abstract}
A ética e a moralidade, agora em íntima conexão com a religião, passaram a exercer uma influência sem precedentes sobre as massas. Com esta nova reestruturação da religião, da ética e da política sobrevieram ainda outros reajustamentos de interesse vital para a educação. A religião perdeu a sua afinidade anterior com a cultura estética e com a literatura; a filosofia, a sua íntima conexão, por meio da ética, com a vida prática. Esse novo caráter moral e religioso da educação, que excluía as fases estéticas e intelectuais tão essenciais para a educação do mundo clássico, persistiu por muitos séculos.
\end{abstract}

O afastamento da religião em relação à política, já é anunciado algum tempo antes, no decurso que resultou na consolidação do pensamento primitivo cristão, e é observado por Fustel de Coulanges:

Mas, pouco a pouco, como já vimos, a sociedade se modificou. $\mathrm{O}$ direito e o governo se trans- formaram ao mesmo tempo em que a religião. Já nos cinco séculos que precedem o cristianismo, a aliança não era mais tão íntima entre a religião, de uma parte, e o direito e a política, de outra. Os esforços das classes oprimidas, a decadência da casta sacerdotal, o trabalho dos filósofos, o progresso do pensamento haviam abalado os velhos princípios de associação humana. Fizeram-se incessantes esforços para libertar o homem do império da antiga religião, à qual o homem não podia mais crer; o direito e a política, como a moral, haviam-se pouco a pouco desembaraçado de seus laços.

Revelam-se muito importantes as questões aqui levantadas, haja vista que a temática oferece possibilidades de entendimento quanto às origens das práticas educativas catequéticas produzidas pela Igreja e o significado destas, este percebido nas representações próprias da tradição ocidental cristianizada e que cumprem um papel crucial na consolidação da nossa cultura, referências essenciais nos processos de pesquisa no âmbito da história da educação. Tal referência atua como um meio amplificador da problematicidade, isto é, densifica o conjunto de problemas concernentes ao objeto: como uma tradição pedagógico-catequética, tão bem fundamentada e com um amplo raio de ação, estando presente em diferentes culturas. Diante dessa realidade, reitera-se, no presente estudo, a necessidade de se produzir uma genealogia da pedagogia da catequese proposta pela Igreja Católica. Alinhando-se ao pensamento nietzscheano-foucaultiano, pretende-se, neste artigo, proceder a uma investigação da história com o objetivo de identificar as relações de poder, campo fértil para ideias, valores e crenças que operam como suportes da prática pedagógico-catequética da Igreja Católica.

O termo pretender afigura-se como o mais adequado, no entendimento deste estudo, pois o termo origem, isto é, um ponto inicial de uma ação ou coisa que tem continuidade no tempo e/ou no espaço, não se apresenta como uma realidade necessária. A situação mais próxima a isso é a percepção, por parte do pesquisador (mesmo e principalmente num exercício genealógico), dos motores que sugerem ações que se manifestam como resposta. Tal limitação hermenêutica é observada por Certau, quando observa que 
Mesmo remontando incessantemente às fontes mais primitivas, perscrutando nos sistemas históricos e lingüísticos a experiência que escondem ao se desenvolverem, o historiador nunca alcança a sua origem, mas apenas os estágios sucessivos da sua perda.

Assim é que o presente estudo opera com possibilidades, a partir da interpretação dos eventos, buscando não uma continuidade, mas, a constância do discurso (que o olhar da pesquisa deve estranhar), vale dizer, de dada perspectiva aplicada ao mundo.

\section{Temor: sentido doutrinal e pedagógico}

O termo, temor, deve ser compreendido como um sentimento de profundo respeito e obediência. Jamais no sentido de terror, de pavor irracional. Em suas raízes etimológicas, o termo pressupõe um estado de reverência. Com efeito, o temor a Deus, o "temor do Senhor" é sentimento esperado naqueles que inspiram seus atos na sabedoria, pois "O temor ao Senhor é o princípio da sabedoria. Os insensatos desprezam a sabedoria e a instrução" ; isto é, "O temor ao Senhor é o princípio da Sabedoria e o conhecimento do Santo é a inteligência". Ao citarem-se os Provérbios, busca-se com isso não só ilustrar as condições em que se percebe o tema, mas, também, demonstrar que se reconhece o texto bíblico como documento histórico. Percepção esta validada em Le Goff:

A história nova ampliou o campo do documento histórico; ela substituiu a história de Langlois e Seignobos, fundada essencialmente nos textos, no documento escrito, por uma multiplicidade de documentos: escritos de todos os tipos, documentos figurados, produtos de escavações arqueológicas, documentos orais, etc. Uma estatística, uma curva de preços, uma fotografia, um filme, ou, para um passado mais distante, pólen fóssil, uma ferramenta, um ex-voto são, para a história nova, documentos de primeira ordem.

No campo educacional da Antiguidade cristã, os agentes formadores cristãos, os Padres Apostólicos, servir-se-ão do termo no intuito de orientar os educandos pelo caminho da retidão, da piedade. Segundo Ruy Afonso da Costa Nunes,
Quando examinamos os escritos dos Padres Apostólicos, os primitivos documentos cristãos, compostos depois do Novo Testamento, verificamos que todos se referem da mesma maneira à educação. Tanto a Didaqué, como a Carta de São Clemente aos Coríntios, a Carta de São Policarpo aos Filipenses e a Carta de Barnabé, contém idêntica expressão: educar os filhos no temor do Senhor, no temor de Deus.

O temor de Deus é, no pensamento educador dos padres apostólicos, um princípio pedagógico, portanto pressupõe métodos que visem à adaptação do indivíduo ao discurso proposto, isto é, nesse caso, ao conteúdo da doutrina: o medo deve dar lugar à reflexão, à meditação constante na Palavra. Processo consequente do se tornar ciente da necessidade de união do conhecimento com a fé, ciência e crença, na compreensão distintiva que sabe, diante do caminho bifurcado, escolher qual das direções leva à redenção através das práticas de piedade e justiça, o que implica no cumprimento rigoroso dessas práticas. Eis então a condição de temor - essência da educação cristã.

A educação e a instrução das crianças à luz das Sagradas Escrituras, orientação proposta pelos Padres Apostólicos, se voltou para as coisas do espírito (condição de imaterialidade, incorporeidade, pura inteligência, consciente de si; pertença do campo religioso, espaço estruturante da Igreja), esclarecendo aos catecúmenos, isto é, àqueles que recebiam as noções preliminares da doutrina, durante o processo de admissão entre os fiéis, quanto a nítida separação entre o que pertenceria à cidade dos homens e os assuntos próprios da cidade de Deus. A educação, sob a perspectiva da Igreja primitiva, é uma transmissão de saber revestida de um significado preciso, rigoroso, que não supõe ampliação (senão renovação), mantendo-se aferrado a um princípio. $O$ exercício pedagógico se dá nesse sentido:

É preciso tomar cuidado, pois para a Igreja antiga o termo tem um sentido mais estrito e mais profundo: trata-se essencialmente da educação religiosa, isto é, de uma parte, da iniciação dogmática: quais são as verdades em que precisamos acreditar para sermos salvos; e, por outra parte, da formação moral: qual é a conduta que convém ao cristão? 
O "temor do Senhor" é mais que uma expressão semanticamente carregada. É a condição de referência que mantém o discurso de separação entre o mundo profano e o mundo espiritual. E a distinção se dá, também, na observância dos ensinamentos. O cristão compromete-se em se manter afastado do que era considerado como leviandade própria das práticas pagãs. O catecúmeno apreende as lições através de arrazoados que the apontam as impressões simbólicas (peixe, âncora, pomba) permitidas e as proibidas (gládio, taça). A pedagogia dos padres apostólicos significou uma forma de reação contra o que o cristão entendia como sendo uma sociedade totalmente corrompida. Nos estertores da até então predominante cultura pagã greco-romana, a educação oferecida pela Igreja primitiva possibilita alternativas ao ensino meramente estético-intelectual. Padrões de vida, de relacionamentos sociais, incluindo valores morais, sofrem alterações. A história do Ocidente na forma que se passa a conhecer - e comunidades dela fazendo parte como produto cultural - se estabelece. Um novo estado ideal de evolução material, social e cultural para o qual se volta então a humanidade. $E$, no que concerne a educação, observa Monroe:

Durante mil anos a educação ia agora caracterizar-se pela ausência de elementos intelectuais. A Igreja primitiva estava lançada na reforma moral do mundo, na destruição do estado social já descrito; por esta razão ela voltava toda a sua atenção para a educação moral dos seus próprios membros e desse modo para a regeneração da sociedade.

A Igreja primitiva tomou como norte o pensamento paulino. A Paideia cristã bate à porta dos lares, buscando preservar sua essência sagrada, seu compromisso verbal transcendente. Portanto, de acordo com Marrou, essa educação afasta-se do método profano, que reconhece a escola como local propício ao ensino. A pedagogia será aplicada pela Igreja, e alcançará o seio da família:

Educar cristamente os filhos, fazê-los participar do tesouro da fé, inculcar-lhes uma sã disciplina em matéria de vida moral é o dever fundamental dos pais: aí há algo mais do que encerrava a tradição romana: o cristianismo depende aqui essencialmente da tradição judia, que aquela prolonga e na qual a tônica posta sobre o papel da família na formação da consciência religiosa era muito acentuada.

Segundo Marrou, o meio cristão é compreendido como o ambiente natural em que se deve formar a alma da criança. Leva-se em consideração o exemplo dado pelo adulto, ainda que, ressalva o autor, não se exclua a tarefa cuidadosa da pedagogia religiosa. Na patrologia grega encontrar-se-á um paladino da pedagogia cristã: o padre apostólico São João Crisóstomo, que elaborou um tratado sobre educação infantil, onde exige que os pais se obriguem a educar seus filhos através das Sagradas Escrituras. Mas (já se disse) o ambiente familiar não contempla in totum às necessidades inerentes aos procedimentos pedagógicos. Esses devem obedecer a uma seqüência contínua de ações. Uma sistemática que compreende, em seus primórdios, a necessidade da educação cristã depender diretamente de um corpo social organizado sob a orientação de uma autoridade eclesiástica. Quanto a isso, observa Marrou:

Por mais importante que seja este papel da família, ele é apenas subsidiário: o essencial da educação religiosa é representado pela iniciação doutrinal que o neófito recebe da Igreja antes de ser batizado. Morfologicamente, o cristianismo é uma religião de mistérios: caráter bem apagado hoje, em virtude de tudo o que subsiste, em nosso mundo paganizado, da cristandade medieval (em nossas igrejas, de portas abertas, não importa quem entre e um pagão pode assistir nela ao mistério eucarístico), mas que era bem claro na Antiguidade cristã.

O catecumenato, um tempo de iniciação no sentimento de respeito pelos Mistérios (não, necessariamente, na revelação), é o meio em que se dá a conversão no cristianismo; e deve ser, para os fins deste artigo, seriamente observado. É uma transformação de valores (crenças e costumes). Os neófitos necessitam de apoio da comunidade cristã, a qual os estimula em seu empenho na mudança. Segundo Pellistrandi,

No século II, leigos tomam o lugar dos instrutores, algumas leituras e conferências completam a formação. Mas no século III, com o aumento do povo de Deus e dos que aspiram a ele per- 
tencer, uma preparação mais estruturada é posta em prática: a catequese.

Mais do que palavras de apoio, de boas-vindas, a catequese exercita a exortação (isto é, a orientação para que os convertidos ajam de acordo com suas consciências e sob o signo da justiça, na explicação oral, sermonística e metódica quanto aos mistérios da fé) ao "temor do Senhor". Para os padres mais radicais, como no caso de Tertuliano (160-225 a.D.), convertido ao cristianismo em 197, não se nasce já cristão, mas, sim, aprende-se a sê-lo.

O século Il vê a Igreja empenhar-se em, aos poucos, fazer com que o discurso pedagógico cristão ultrapasse o seio familiar e as reuniões comunitárias para alcançar as escolas, onde estão as crianças e os jovens, futuros indivíduos constituintes de uma nova forma de viver; e seus mestres se encontram entre os "muitos filósofos e sofistas [que], cansados de uma religião inteiramente desprovida de espiritualidade, passam para o cristianismo". E esses intelectuais não abdicam da investigação em nome do conhecimento. Na verdade, exibem seu saber com orgulho. É claro, portanto, que o saber oriundo das fontes pagãs não desaparece, simplesmente. Ocorrerão, assim, conflitos, a partir de suas maneiras de elaborar sistemas de compreensão do mundo, comenta Pellistrandi: "Não se trata, portanto, de que as crianças cristãs abandonem a escola romana. Porém, estudarão as obras greco-latinas desvencilhando-se do paganismo de seus autores".

No "temor do Senhor", como princípio pedagógico, a criança será valorizada, e é o Evangelho o guia de conduta que afasta os iniciantes dos hábitos pagãos ainda subsistentes entre os membros das comunidades, como o poder de preservar a vida ou condenar a morte, poder este conferido ao pai pelo Direito Romano. $\mathrm{O}$ cristianismo primitivo modifica essa relação, buscando substituir o poder pelo cuidado paterno para com os filhos. Segundo Pellistrandi: "a Igreja procura principalmente despertar nos pais a consciência de uma responsabilidade educadora".
Sob a égide de uma prática pedagógica que se orienta pelo "temor do Senhor", a educação cristã, conforme Pellistrandi e Marrou, orientará a valorização da criança. O que implicou na modificação de perspectivas quanto à sua formação. A disposição e a ordem dos elementos essenciais que constituíram a organização familiar greco-romana são profundamente modificadas. O pai torna-se um educador, devendo resguardar em justas proporções a sua autoridade, reproduzindo a "pedagogia divina". E quando o rebento entra em contato com a escola clássica, as recomendações são claras. Eis, sobre esse cuidado, o que colhemos em Marrou:

\footnotetext{
A criança, o adolescente cristão será educado, como os pagãos, na mesma escola clássica; receberá sempre o "veneno" que são Homero, os poetas, o cortejo insidioso das figuras da Fábula, as túrbidas paixões que elas patrocinam ou encarnam. Conta-se, para imunizá-la, com o contraveneno representado pela educação religiosa que Ihe é dada, fora da escola, pela Igreja e pela família: sendo sua consciência religiosa devidamente esclarecida e formada, a criança saberá efetuar as correções e as distinções necessárias.
}

O "temor do Senhor", como princípio pedagógico nas práticas educativas dos Padres Apostólicos na Antiguidade Cristã, é referência necessária à formação de um espírito discernente, isto é, o catecúmeno, no caminho de salvação, saberá corrigir o rumo sempre que necessário, percebendo as diferenças, sabendo das exigências às quais deve se submeter num claro esforço de renúncias. Clemente de Alexandria, São Jerônimo, Tertuliano São Basílio: eis, entre outros, homens de fé, padres apostólicos, mas, também, práticos educadores que se dedicaram à defesa e propagação uma Paideia aplicada conforme a Lei de Deus, cientes de que, no campo em que se dão as práticas educativas ao fim do mundo antigo, na emergência do pensamento cristão, o educador deverá ser o dirigente que aponta o percurso ao longo do qual espírito e cultura, em comunhão, serão os instrumentos auxiliares nessa espécie de exercício salmódico que levará o indivíduo à sabedoria. 